(昭和 46 年 10 月 25 日受理)

$$
\begin{aligned}
& \text { パークロルエチレンからの分散染料 } \\
& \text { によるポリエステルの染色 } \\
& \text { 大阪府立大学工学部片山明・黑木宣应 } \\
& \text { K K 大租川染工新北野靖典 }
\end{aligned}
$$

\title{
DYEING OF POLYESTER WITH DISPERSE DYES FROM PERCHLOROETHYLENE
}

\author{
By Akira Katayama*, Yasunori Kitano** and Nobuhiko Kuroki* \\ * (Department of Applied chemistry, University of Osaka Prefecture, \\ Sakai City, Osaka, Japan) \\ *** (Yamatogawa Senkoshyo Co., Ltd., Sakai City, Osaka, Sapan)
}

The purpose of this work is to obtain the information on the dyeing behavior of polyester with disperse dyes from a perchloroethylene solution. The absorption isotherms for C.I. Disperse Red 88, azo-type, (I) and C.I. Disperse Red 60, anthraquinone-type, (II) were determined at $5^{\circ} \mathrm{C}$ intervals from $100^{\circ}$ to $120^{\circ} \mathrm{C}$, using polyester film. The absorption isotherms obtained were linear for all dyes. From the absorption isotherms, the partition coefficient and the heat of dyeing were calculated. The partition coefficient ranged from 8-14 for dye (I) to $0.6-0.7$ for dye (II). These values are much smaller than for aqueous dyeing at the same temperature. The heats of dyeing for dye (I) and dye (II) were -7 and $-2 \mathrm{kcal}$, respectively. These values are larger ca. $4 \mathrm{kcal}$ than for aqueous dyeing. The diffusion coefficient in the substrate for dye (I) and dye (II) were determined at various temperatures by means of film roll method. The polyester film used was pretreated in a blank dyebath at $120^{\circ} \mathrm{C}$. The diffusion coefficients thus obtained did not show any dependency on the concentration of the absorped dye in the film. The diffusion coefficient ranged from $2.56 \times 10^{-9}-2.74 \times 10^{-8}$ for dye (I) to $1.87 \times 10^{-8}-5.91 \times 10^{-8} \mathrm{~cm}^{2} / \mathrm{min}$ for dye (II). These diffusion coefficient are much larger than for aqueous dyeing. From the temperature dependence of diffusion coefficient, the activation energies for diffusion were calculated for dye (I) and dye (II). They were 32 and $17 \mathrm{kcal}$, respectively, which are smaller than for aqueous dyeing. From the results obtained in this work, a schematic drawing for swollen polyester in perchloroethylene was obtained.

(Received October 25, 1971)

\author{
1. 緒 \\ 言

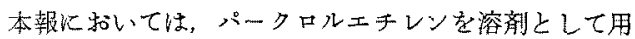 \\ いた場合の分散染料の染色挙動を，水を用いた場合のそ \\ れと比輍检討した。 \\ 最近水のかわりにパークロルエチレンを溶剤として用 \\ いる，いわゆる溶剤染色が多くの関心を集めている。

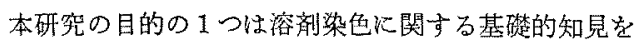 \\ 得ることである。 \\ また，水は分子間水瑟結合以基つく強い集合性を有す \\ るのに対し，パークロルエチレンはこのよらな特異的集
}

合性をむたないため，その溶液の学勳は水の場合に比べ てはるが簡単ですり，理想溶液のそれk近いことが期 待される。本研究の目的の他の一つは，この上うなより 簡単な系以ついての染色举勤を調へ，染色現象を明らか にする一つの手がかりとすることである。 パークロルエチレンーポリエステル系の染色学動改つ いては，すでに2，3の報告 ${ }^{123}$ があるが，艺れらはいず れも種々の溶剂括よび基質の組み合わせの中の一つとし て取り上げら礼たものである。本報にお゙いては，対象を パークロルエチレンーポリエステル系のみにかぎり： の系についてより詳細な検討を行なうこととした。 
すなわり，2種の分散染料を用いて，水系およびパー クロルエチレン系でのポりエステルの染着平衡扎よび染 料の基筫内桩散を調べ，艺の結果を染料分子の溶剂に対 する親和性扣上び染料分子の大ささ考考慮して考察を行 なった。

\section{2. 試料および実験方法}

\section{1 試 料}

基筫としてはマイラーフィルム（等さ約 $6 \mu$ ）用い， 水系の場合には水浴で $130^{\circ} ， 30$ 分間，パークロルエ レン系の場合にはパークロルエチレン涸で $120^{\circ} ， 30$ 分 間処理を行なった。なな。熱処理は、処理中にフィルム に折机目がつくことをさ斿るため, フィルムをガラス棒 に汤るく卷きつけた状態で行なった。

フィルムの厚さは、McDowell、 Weingartini)の方法 Kしたがい，400〜700 m $\mu$ の波長の光を用いてフィル ムの透過度を測定し，次式纪より計算によって求めた。

$$
\frac{2 d+\lambda_{m}}{2 d}=\frac{\lambda_{m}}{\lambda_{m+2}}
$$

ここで，dはフィルムの厚さ， $\lambda_{m}$ むよび $\lambda_{m+2}$ は去 机ぞれ $m$ 番目枯よび $m+2$ 番目の谷の波長で等る。

染料と乙て忙 C.I. Disperse Red 88 战上び C.I. Disperse Red 60 の2 種を選んだ。前者は，アゾ采分散 染料であり，分子の形が比較的大きく，此較的親水性の 染料でる。一方，徭者は，アントラキノン系分散梁样 であり，分子の形が比裁的小さく，比較的蹯水性の染料 である。前者は，水一メタノール（1:1 容量）混合溶液

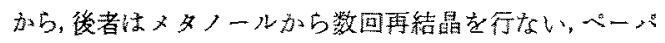
ークロマトグラム法で純品と思われるものを使用した。

Red 88 拈よびRed 60 の分子量, 融点蛒よびパーク ロルエチレンに対する溶解度 $\left(100^{\circ}\right)$ を第 1 䓂に示し た。な拓，用いた染料の構造式は未公表であるので表中 比示さなかった。

また，ハークロルエチレン（東亚合成は，染色期間 中の变質をさ计るため，安定绪を含んだまま使用に供し *。

\section{2 実験方法}

平衡染着量……熱処理を行なったマイラーフィルム約 $50 \mathrm{mg}$ 在精秤し，所定温度で所定時間，器限大染浴とし

Table 1. Properties of the dye

\begin{tabular}{c|c|c|c}
\hline Dye & $\begin{array}{c}\text { m.p. } \\
{\left[{ }^{\circ} \mathrm{C}\right]}\end{array}$ & M.W. & $\begin{array}{c}\text { Solubility in perch- } \\
\text { loroethylene at } \\
100^{\circ} \mathrm{C}[\mathrm{g} / \mathrm{kg}]\end{array}$ \\
\hline $\begin{array}{c}\text { C. I. Disperse } \\
\text { Red 88 }\end{array}$ & $202-204$ & 428 & 0.23 \\
$\begin{array}{c}\text { C.1. Disperse } \\
\text { Red 60 }\end{array}$ & 182 & 331 & 74 \\
\hline
\end{tabular}

て取り扱らに十分な量の染液を含む染浴から染色した。

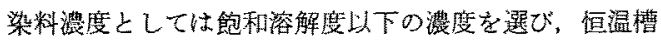
としてはグリセりン浴を用いた（温度精度 $\pm 0.5^{\circ}$ )。

水柔の場合は, 内容 $1000 \mathrm{ml}$ の耐王ガラスビンを用 い $115^{\circ}$ から $130^{\circ}$ まて $5^{\circ}$ 間隔で桇色を行なった。

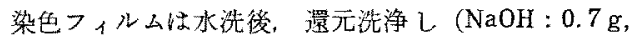
ハイドロサルファイト: $1 \mathrm{~g}$, スコアロール900:1 g/ $500 \mathrm{~m} l, 90^{\circ}, 30$ 分間)，ふたたび办洗して乾燥した。

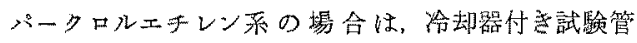
$(6 \mathrm{~cm} \times 25 \mathrm{~cm})$ を用い， $100^{\circ}$ から $120^{\circ}$ をで $5^{\circ}$ 間隔で 染色を行はった。染色フィルムは、パークロルエチレン 浴中, 常温で 3 分閏洗浄する操作を 2 回くり返し, 翰燥 Lた。

染色平衡に到達するに要する時間は，水系で5 時間， パークロルエチレン亲で 3 時間で十㔔で市った。

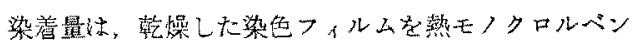

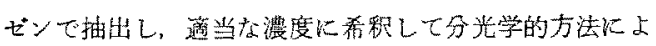
って決定した。

抬散係数……染料の基筫内桩散俰数の決定はつィルム 巻層法り によった。。染色条件としては，無限浴から半無 限体一の搪散が成立する条件を，ま大搪散㭙間忹，巻層 の啳の 6 8 吸光度が 0.1 以上 (パークロルエチレンー Red 60 采に怙いては0.06以上）となるよう選んだ。

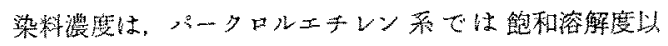
上，水采では染料妾 $0.5 \mathrm{~g}$ デモール $1300 \mathrm{ml}$ 水中に分

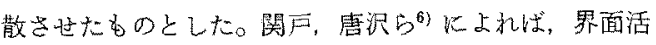

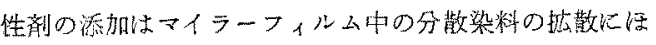
とえと影響を与克ない。

水系の場合は，古ら方じ熱処理した $4 \mathrm{~cm} \times 50 \mathrm{~cm}$ のマイラータィルムを。 $0.1 \mathrm{~g}$ スコアロール900/500 $\mathrm{m} l$

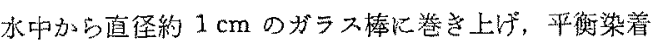
の場合と同じ耐医ガタスビンを用いて掋散実駼を行なっ

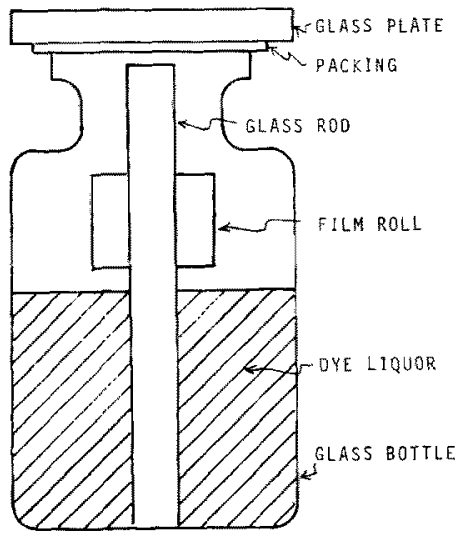

Fig. 1. Dyeing apparatus for aqueous dyeing. 
た。

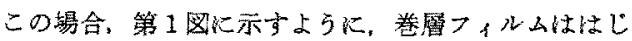
め染浴と接しない状態保持していき，染浴が温度和よ

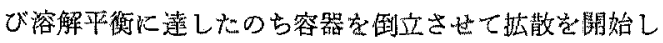
たo

また，㧓散の停止は，容器をもとの状態にもどして管 層が染浴と接しない状態とし，しばらく放冷したのb容

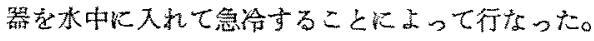

パータロルエチレン系の教命は, パータロルエチレン

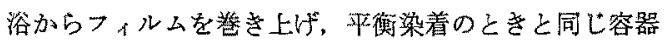

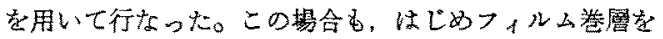
冷却管を通したガラス棒によって染浴と接しない状態に 保持して扣き，染浴が温度佶よで溶解亚衡に達したのら ガラス棒を押し下げて拡敨を開始させるようにした。

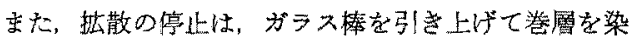
溶から取り出すことによって行なった。

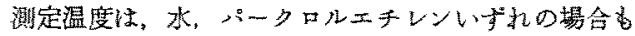
それぞれ平衡実验の場合と同㮞とした。またフォルム

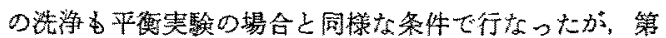
1 買に付着した染料を完全に除去することが困鹳であっ

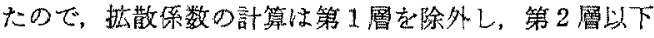
についての行なった。

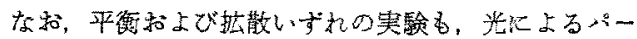
クロルエチレン就ざ染料の分解をさけるため，光を遮 䉼したドラフト中で行なった。

\section{3. 結果}

\section{1 染着等温曲線}

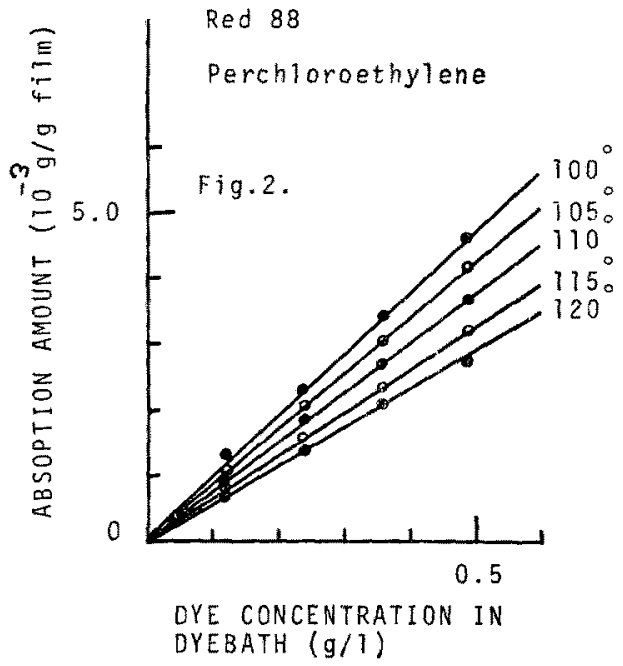

Fig. 2. Absorption isotherms of polyester film for Red 88 in perchloroethylene.

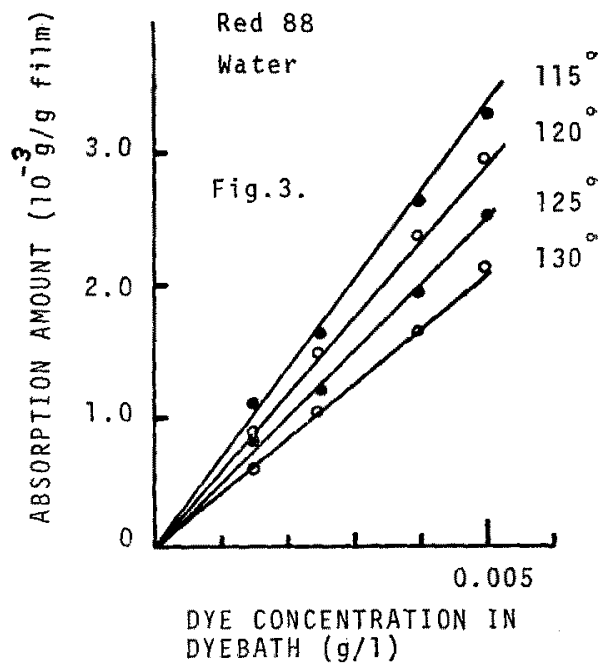

Fig. 3. Absorption isotherms of polyester film for Red 88 in water.

Red 88 心つて得られた染着等温制線の結果を第 2 括よび 3 图に示した。第2 図は水系に，第3 図はパーク

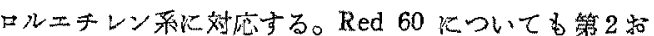
よび 3 困と同様な結果が得られた。

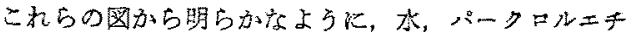
レンいずれの系に拀いて本，得られる染着等温曲線性分

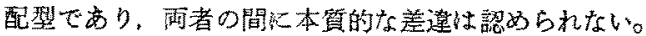

このような結果梳，他の研究者によって指摘されてい

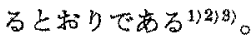

得られた染着等温曲線の結果加的匴した Red 88 标 よび Red 60 の分配係数，Kの值定第 2 表に示した。

ただし，分配䃄数は次式によって計箱したbのです る。

$$
K=[D]_{F} /[D]_{s}
$$

(2) 式に括いて， $[D]_{F}$ 特よび $[D]_{S}$ は，艺れぞれつ

Table 2. Partition coefficients of Red 88 and Red 60 in polyester-perchloroethylene and -water systems.

\begin{tabular}{c|c|c|c|c}
\hline $\begin{array}{c}\text { Temp. } \\
\left({ }^{\circ} \mathrm{C}\right)\end{array}$ & \multicolumn{2}{|c|}{ Red 88 } & \multicolumn{2}{|c}{ Red 60} \\
\hline 100 & Water & $\begin{array}{c}\text { Perchlor- } \\
\text { oethylene }\end{array}$ & Water & $\begin{array}{c}\text { Perchlor- } \\
\text { oethylene }\end{array}$ \\
\hline 105 & & 13.8 & & 0.693 \\
110 & & 12.4 & & \\
115 & 668 & 10.9 & & 0.644 \\
120 & 588 & 8.61 & 5000 & \\
125 & 502 & & 4520 & 0.602 \\
130 & 406 & & 4100 & \\
\hline
\end{tabular}


Table 3. Diffusion coefficients of Red 88 and Red 60 in polyester-perchloroethylene and -water system $\left(\mathrm{cm}^{2} / \mathrm{min}\right)$

\begin{tabular}{l|l|l|l|l}
\hline $\begin{array}{c}\text { Temp. } \\
\left({ }^{\circ} \mathrm{C}\right)\end{array}$ & \multicolumn{2}{|c|}{ Red 88} & \multicolumn{2}{|c}{ Red 60} \\
\cline { 2 - 4 } & Water & $\begin{array}{l}\text { Perchlor- } \\
\text { oethylene }\end{array}$ & Water & $\begin{array}{l}\text { Perchlor- } \\
\text { oethylene }\end{array}$ \\
\hline 100 & & $2.56 \times 10^{-9}$ & & $1.87 \times 10^{-8}$ \\
105 & & 4.27 & & 2.74 \\
110 & & 7.57 & & 3.05 \\
115 & $2.02 \times 10^{-10}$ & $1.16 \times 10^{-8}$ & $1.97 \times 10^{-9}$ & 3.65 \\
120 & 4.19 & 2.74 & 3.94 & 5.91 \\
125 & 7.78 & & 7.01 & \\
130 & $1.19 \times 10^{-9}$ & & $1.49 \times 10^{-8}$ & \\
\hline
\end{tabular}

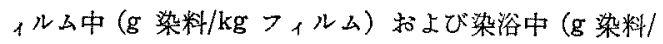
$\mathrm{kg}$ 溶液) の染料濃度である。

第2表にみられるように，い寸゙れの染料に拉いてもパ 一クロルェチレン系の分配係数は水系のそれに比べてい らしるしく小さい。このよらな結果は他の研究者のそれ と一致している ${ }^{1 \sim 9}$ 。

そしてこの場合，瑓水性の Red 60 に拈いてこのよう な傾向はとくに顕著に現われるが，このことは水拉よび パータロルエチレンに対する染料の溶解性を考虑すれば 現象的にはらなつけることである。

\section{2 㹡散 係数}

奏稌によって得られた各尿の濃度から，関戸一烃井の

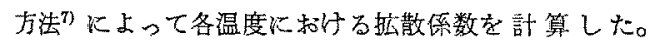
Red 88 お゙よび Red 60 の結果を第3表に示した。

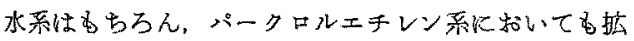
散係数の濃度依存性俈認められなかったので，染料の基 質内拡散は Fick 型であると考えられる。このことは森 田，内村炕よって指摘されている。

第3表から明らかなよらに，パークロルェチレン系の 昿散係数は水系のそれに比べてかなり大学い。

このような結果す他の研究者のそれと一致している $1-3)$ 。

第3表の結果を用いて計算した拡散の活性化エネルギ

Table 4. Activation energy, activation entropy, heat of dyeing and energy required to make a hole through which dye molecule diffuses in substrate of $\operatorname{Red} 88$ and $\operatorname{Red} 60$ in polyester-perchloroethylene and -water systems.

\begin{tabular}{lr|r|r|r|r}
\hline & \multicolumn{2}{|c|}{ Red 88 } & \multicolumn{2}{|c}{ Red 60 } \\
\cline { 3 - 6 } & Water & $\begin{array}{l}\text { Perchlor- } \\
\text { oethylene }\end{array}$ & Water & $\begin{array}{l}\text { Perchlor- } \\
\text { oethylene }\end{array}$ \\
\hline Activation energy & $(\mathrm{kcal} / \mathrm{mol})$ & 42 & 32 & 39 & 17 \\
Activation entropy & $($ e. u. $)$ & 115 & 108 & 125 & 84 \\
Heat of dyeing & $(\mathrm{kcal} / \mathrm{mol})$ & 11 & 7 & 6 & 2 \\
Energy to make a hole $(\mathrm{kcal} / \mathrm{mol})$ & 31 & 25 & 33 & 15 \\
\hline
\end{tabular}

一の值を第 4 表中に示しだ。

パークロルエチレン系の抾散の活性化エネルギーは， 水莱のそれに比べてかなり小さく，10〜20 kcal ていと 小さな值となっている。橋本，山岸2は，溶媒の種類に よって执散の活性化エネルギーはあまり変化しないとし ているが, 森田, 内村 ${ }^{3)}$ は著者らと同様な結果を得ている。

\section{4. 考察}

\section{1 平 衡}

パークロルニチレン系に打ける染料の分配保数は，水 系のそれと比べていらしるしく小さいことは3.7節にお

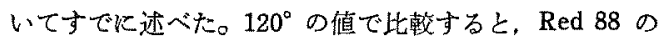
場合恃約 70 分の 1, Red 60 の場合には約 7500 分の1 にすぎない。

このような事実は，声として染料のパークロルェチレ ンに対する溶解性が大きいことに基ら゙くあのと考えられ るが，その原因以ついてい少し詳紐に教ててよら。

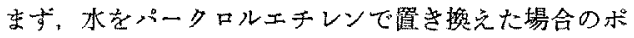
リエステルの染着有效体積の变化について考克る。

本報においては，平衡実験炕よってフィルムの飽和染 着量を決定することは行なっていないのでその結果か b染着有効体穔についての考察を行ならことは不可能で ある。しかし, 本報の場合, 染料の搪散係数の濃度依存 性は認められていないので, 2 層以下の巻層内の濃度分 布から巻層表面濃度を計算によって求わることは理諭的

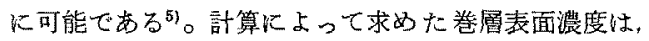
パータロルエチレン系の場合，水系の場合の医卧 2.5 分 1 のにすぎなかった。

しかし，パータロルエチレン系に扎いても，氷系に抽 いてもともに染浴には飽和溶解度以上の染料が含まれて いるので，いずれの場合す溶液中の染料の活動量は固体 染料のそ机と等しい。したがって，基犋の染着有効体䅡 に差違がながりり、いずれの系に就いてす表面濃度は 等しくなることが期待される。

以上のことを考慮すると，上述の表面浀度の差遠は染 着有効体積の差違を示寸ものと考方 られ、パークロルェチレン系での基 貿の染着有效体積は，水系でのそれ 汇比べて小さく，2.5 分の 1 でいど と推定される。

したがって, パークロルエチレン 系の染料の分配原数が水系のそれに 比べていらしるしく小さくなる原因 の一部媣着有効体積の娍少が関与 しているるのと考えられる。たた し，以上の考察に和いては，パーク 
ロルエチレン系, 水系いずれの場合にす染着状態に変化

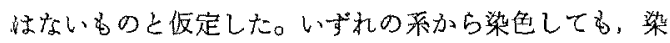

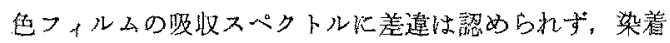

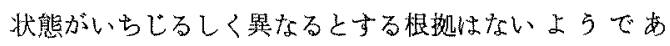
D。

つぎに，エネルギ一的因子について考察するため，第 2 表の結果を用いてパータロルエチレン系拈上び水系仙 ついての染色熱を計算すると第 4 表のよらな結果とな 万。

第 4 表から明らかなよらに， Red 88，Red 60 いずれ

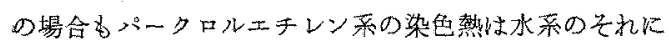

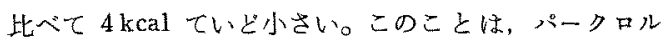
エホレン采での分配係数が水系のそれ炕比でていらじる しく小さい原因としてエネルギ一的因子が大きな微割を 演じていること意味する。

ここで，ハータッル土キレン系乩よび水采の染色熱の

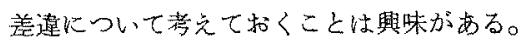

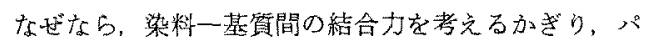
一クロエレン系の染色熱が水系の々れK比べて小さく ならなけ敞ばならない理由が見当らないからでする。

た之えば，染料分子一基貿間の水素結合を考劣ると， 水柔に执いては両者の間に水素結台が形成されるために は，まず染料分子および基質の水素結合形成能基と結合 している水分子を切断することか心必要である。一方，市 ークロルエチン系に战いてはこのよらな必爱はないので 水素結台の形成ははるかに容易なはずである。

したがって，水系比いて染色熱が大きく現われる理 由は，染料一基質間相互作用が大さいためではなく，壳 しる染料聎水部心よって切断されていた水分子間水素結 合功染料の基貿内への移行によって回復するためと考克

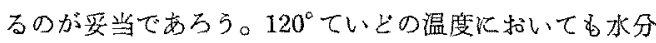
子がな打水素結合によって連結されていることはLuck の研究結果なとから明らかである。

このょうに，水系での染着に和いては，水自身の大き な分子間相互作用が重要な役創を演じているのに対し， パークロルエチレン系のそれに执いてはこのような筒与

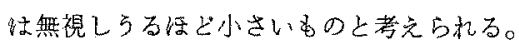

なお，分配係数に拉よばすント口ピー的因子の寄与 は興味ある問題であるが，本報の䈇团内ではパークロル エチレン系技よび水系に和ける染着有効体瀷を正しく見 積ることができないのてふふれない。

\section{2 㹡 散}

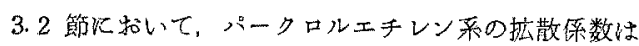
水系のそれに比べてかなり大きく，拡散の活性化エネル ギーはかなり小さいことを述へた。

吉田 ${ }^{9}$ が指摘しているよらに，抬散の活性化エネルギ
一は（I）染料分子を基質高分子鎖から引き雄すに要する ニネルギーと（II）基質高分子鎖間に染料分子の通過する に十分な大ささの空触を作る㴗するエネルギーの和と 考党ることがでさる。

このらち，（1）のエネルギーは，漞水性緎維比沶いて は染色熱と等しいと近似することができる。しかし，眯

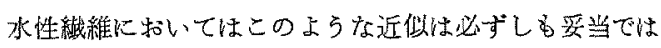
ない。その理由は次のと和りである。

染色蓺山，染浴中に执いて完全に溶媒和された染料分 子のポテンシャルエネルギーと基筫中に吸着された染料 分子の穵れとの差等しい。一方，(I）のエネルギー は，染料分子を基筫高分子鎖加ら引離す以要寸るエネ

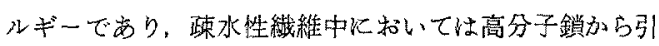
き雄された染料分子が染浴中に和忷吕之同㥞に完全に溶 媒和されているかいなかについては疑問がある。

しかし，本報化和いては，ごく粗い近似として（I）の エネルギーを染色浲をbって代用し，活性化エネルギー

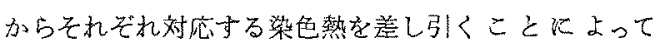
(II)のメネルギーを見積ることとした。第 4 表中にその 結果を示した。

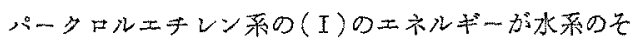
れ比ベて小さいこと海染熱の結果から推定すること ができるが，第7表の結果以よれば(II)の土ネルギーも かなり小さい。

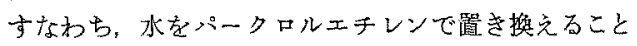
によって，Red 88 で約 $6 \mathrm{kcal}$, Red 60 で約 $18 \mathrm{kcal}$ (II)のエホルキ゚ーは小となる。

この瑒合，染料分子が比較的小さい Red 60 K和いて (II）のエネルギーの傦少が顛著であることは與味があ る。

な怙，第 7 表の結果炕よれば，分子の大きな Red 88 の水系に拈ける(II)の土ネルギーは分子の小さなRed 60 のそれ比べて小となっている。このような結果性 説明困䧳である。

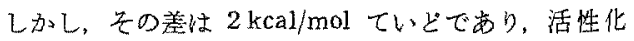

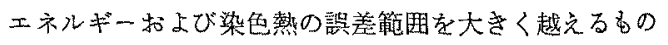
ではないっこのよらな結果が，奏験䛊差によるものか， あるい忧さに述べた（II)のエネルギ一を染色熱で近似 したことに基づくものか，さらにはその他の原因による ものか时明らでない。

つぎに，次式 ${ }^{10}$ に上り应散の活性化エントロピー索計 算してみると第 4 表の上5火なる。

$$
D=e \lambda^{2} \frac{k T}{h} e^{\Delta S^{*} / R} e^{-E / R T}
$$

(3) 式において， $\Delta S^{*}$ 物よびEはとれぞれ拡鞂の活性 化エントロと゚ーおよび活性化エネルギー， kは寺ルッマ 


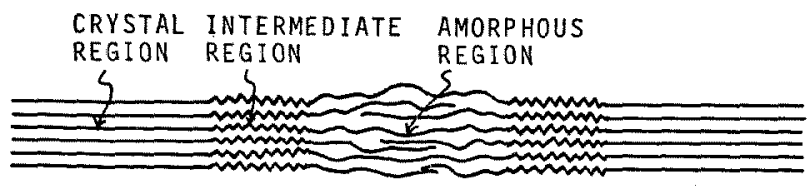

a) CONTROL

b) IN WATER
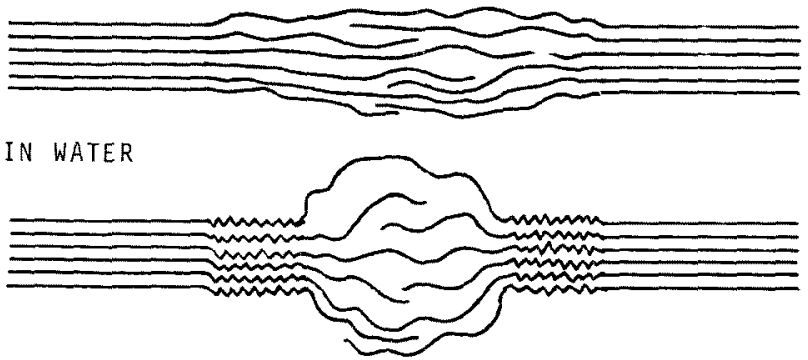

c) IN PERCHLOROETHYLENE

Fig. 4. Schematic drawing of swollen state of polyester in water and in perchloroethylene.

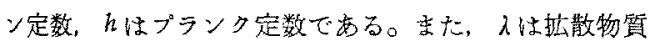
の飛䠰距㒕であるが，本報の場合艺机を正しく見積るこ とが困難であるため入は活性化エントロピーの中に含め $た_{0}$

第4表から明らかなように，活性化エントロピーはい ずれの系炕拮いてもすべて正であるが，パークロルエチ レン䒺のそれは水系のそれに比べて明らかに小さい。

このことは，パークロルエチレン系の拡散保数が水系 のそれに比べて大きいのは活性化エネルギーの寄与によ るものであることを意味する。

それでは，パークロルエチレン系の活性化エネルギー が办系のそれに此べて小さくなるのはとの上らな理由に よるのであ万らか。

㹡散の活性化エネルギーのらち，（Ｉ）についてはすで に考察したので,ここでは(II)についてのみ考光る。

まず，第一に考えられるのは，パークロルエチレン系 と水系に和ける基質の膨潤度の美違である。

しかし、ポリエステル織布をパータロルエチレン中お よび办中で处理したときの収縮率の結果 ${ }^{11)}$ 検討してみ ると(この結果恃非常飞定性的なるのではあるが)，パ ークロルエチレン中での基質の膨潤がとくに影著である 上㛈考化くく、导しる大差ないと考党るのが妥当な上 らである。

そこで，1，パークロルエチレン系，水采いずれの場 合にも基質の膨潤度には大差がない，2，パークロルェ チレン系での基質の染着有効体皘は本系でのそれに比べ て小さい，3. 染料分子が比較的小さい場合，パーク口
ルエチレン系での搪散の活性化エネルギーの減少が顕著 に現っれる、ことなどを考慮すると，水系物よびパーク

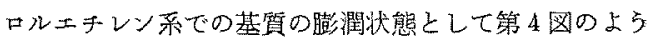
な模式図を想定することができる。

第 4 図，a）飞示すよ5に，基筫恃結晶領域，中間領 域敊よび非晶領域の 3 つの部分からなるものとする。

第4図，b）法，水系に䑙ける膨潤状態を示すもので ある。水分子は小さな分子であるので基質の非晶領域の みならず中間領域の一部老も膨潤させるが，基質が业水 性であるためいずれの領域をも大きく膨潤させることは ない。

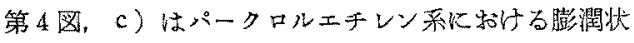
態を示すもので西る。パークロルエチレン分子は大をな 分子であるため基質の非晶領域のみしか膨潤しないが, 基質が䟱水性であるためこの領域を大さ膨潤させる。 以上の上万な模式図を想定すれば，上述の 1，2，3い ずれの事実をる矛盾なく説明することが可能である。 すな⿰ち，第 4 図，b) 括よび c) の比較から，たと党基 質全体としての膨潤度は同じであってもパークロルエま レン采の染着有效体積が氷系のそ机に比べて小さいこ と，また染料分子が小さい结と゚゚ークロルエチレン系の （I）のエネルギーが水系のそ机比べていちじるしく小 さくなることが理解される。

しかし，第 4 図の模式图は，あくまで本報の実鈳範国 内での推定によるものであり，今後上り直接的方法での 检討が望まれる。 
文献

1) Milicévić: Textilvredlung, 4, 213 (1969)

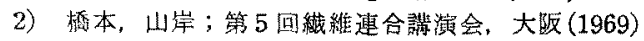

3) 湘田, 内村；日本化学会第 24 年会, 大陑 (1971)

4) McDowell, Weingarten; J. Soc. Dyers \& Colourists, 85, 589 (1969)

5）閏戸，森田；染色工業，13，103（1965）

6) 閶戸，唐呮，寒河汇，丁子; 私信

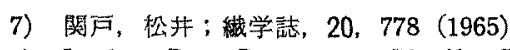

8) Luck; Ber. Bunsenges. Physik. Chem., 69, 626(1965)

9）吉田; 染色工業, 8,389（1960）

10) Laidler, Eyring ; "The Theory of Rate Process" McGraw-Hill, 516 (1941)

11)ベイェルジャハン技術部；架色工業, 19,72(1971) 